\title{
The creation of an eco-tourism site: a case study of Pulau Singa Besar
}

\author{
A. Abdullah, A. M. Abdul Rahman, A. Bahauddin \& B. Mohamed \\ School of Housing, Building and Planning, Universiti Sains Malaysia, \\ Malaysia
}

\begin{abstract}
Ecotourism is the fastest growing form of tourism in Malaysia. It currently makes up about $10 \%$ of the country's tourism revenue. The Malaysian Government, specifically the Minister of Culture, Arts and Tourism has adopted a National Tourism Policy and National Ecotourism Plan (1996-2005) to encourage visitation to rural areas in order to enhance economic development as well as to meet the demands of what was perceived to be increased interest in the natural heritage of the country by the international tourism market. The development of Pulau Singa Besar, a small island off the legendary and more famous Langkawi Island in Malaysia is among one of the many efforts. The importance of sustainable planning, design and management is critical if an ecotourism site is to continue in generations to come. This paper addresses fundamental issues in the planning, design and implementation of various projects on the island of Pulau Singa Besar. It focuses on the lessons learned for future development.
\end{abstract}

Keywords: ecotourism, sustainability, development, design.

\section{Introduction}

In 1987, the concept of sustainable development was first introduced in a report entitled Our Common Future by the World Commission on Environment and Development of the United Nation [1]. According to the Commission, sustainable development is defined as "...development that meets the need of the present without compromising the ability of future generations to meet their own needs." 
Sustainable development has been proposed as a model that can have utility in creating the impetus for structural change within society. It consists of the following four interrelated goals:

- Meeting both present and future needs

- Meeting the needs which define the goal for development

- Maintaining consistency between population size and ecosystem productivity capacity

- Implementing change which acknowledges that the definition of needs and requirements for achieving sustainability will change over condition and time.

Strategies on tourism and sustainability were then discussed during the Globe '90 [2] conference in Canada where representatives from the tourism industry, government, non-government agencies (NGO's) and academics suggested that the goals of sustainable tourism include:

- To develop a greater awareness and understanding of the significant contributions that tourism can make to environment and the economy.

- To promote equity and development.

- To improve the quality of life of the host community.

- To provide a high quality of experience for visitors.

- To maintain the quality of the environment on which the foregoing objectives depend.

In the early 90 's, promoting tourism that is sustainable became fashionable. A lot of individuals and organizations have joined the bandwagon. It gave the opportunity for nature lovers to promote and conserve nature while tour operators do it mainly for economic benefits. Terms such as "ecotourism" became a buzzword. However, the definition of the term became rather confusing. Orams [3] suggested that the term can be traced back to the late 1980s although Higgins [4] argued that Miller's work on eco-development actually dates back to the late 1970s. According to Boo [5], the first person to coin the term was Ceballos-Lascurain, who defined ecotourism as:

"traveling to relatively undisturbed or uncontaminated natural areas with the specific objective of studying, enjoying the scenery and its wild plants and animals, as well as any existing cultural manifestations found in these areas"

According to Goodwin [6], ecotourism should contribute significantly in the preservation of species and habitats either directly through conservation efforts or indirectly, by providing revenue to the local community sufficient for them to protect the wildlife heritage area as a source of income. Laarman and Durst [7] stressed that the visit should combine both, recreation and education. Wallace and Pierce [8] emphasized that true ecotourism addresses six principles:

- It contributes to the conservation and management of legally protected and other natural areas.

- It should generate economic and other benefits

- It should minimize negative impacts to the environment and to local people. 
- It should increase the awareness and understanding of an area's natural and cultural systems and the subsequent involvement of visitors in issues affecting those systems.

- It should increase participation of local people in the decision-making process that determines the kind and amount of tourism that should occur.

\section{Ecotourism in Malaysia}

Since the mid 1990s, ecotourism became the fastest growing form of tourism in Malaysia. At present, it contributes about $10 \%$ of the country's tourism revenue. The Malaysian Government, specifically the Minister of Culture, Arts and Tourism Malayisia has adopted a National Tourism Policy and National Ecotourism Plan (1996-2005) to encourage visitation to rural areas in order to enhance economic development as well as to meet the demands of what was perceived to be increased interest in the natural heritage of the country by the international tourism market. The development of Pulau Singa Besar, a small island off the legendary and more famous Langkawi Island in Malaysia is among one of the many efforts. This paper addresses fundamental issues in the planning, design and implementation of various projects on the island of Pulau Singa Besar. It focuses on the lessons learned for future development.

\section{Pulau Singa Besar}

Located on the North-East of Penang Island, Malaysia, Pulau Singa Besar is one of the four major islands that collectively formed the Island of Langkawi. The island belongs to the Kedah State Government, which presented it to the Ministry of Science \& Technology (MOSTE) to be developed as an ecotourism spot. It was planned to be a showcase of science $\&$ technology. The island was previously designated as a Wildlife Sanctuary. However, the concept has not been successfully implemented and the park was neglected despite abundant natural resources.

USAINS Holding Sdn. Bhd which is wholly owned by the Universiti Sains Malaysia was given the task to materialise the concept. A Project Management Team was formed amongst the three entities viz., USAINS Holding Sdn Bhd., the Department of Wildlife and Kedah State Development Board. USAINS Holding Sdn Bhd. was given an initial implementation budget of RM5 million to carry out several projects. The identified stakeholders are then committed to preserving 636 hectares of Pulau Singa Besar and its surrounding marine environment as a Science \& Technology Park. The mission statement states that the island is:

"... to be managed in a manner that is consistent with the socio-economic aspirations of the people of Langkawi through the innovative and artful applications of science and technology in conserving the rich natural resources, both terrestrial and marine, for the promotion of ecotourism and sustainable development." 


\subsection{Approach to the island}

As an island, Pulau Singa Besar can be accessed from all sides but the main entry point is at the bay. The main jetty is known as the Pulau Singa Besar Jetty where one would normally embark. The most convenient way to visit Pulau Singa Besar from mainland Langkawi would be from the Teluk Baru Jetty or the Awana Porto Malai Jetty.

\subsection{The Infocenter}

The first place that greets the visitors is the Infocenter. Information at the centre gives an overview of what is available on the island. A huge resource of information is available for the visitors in various forms (posters, leaflets, interactive CCTV). This is the first marker (information about the nucleus) as suggested by Leiper [9]. From there the visitors can decide to choose where they would like to go for further observation

\subsection{The Herbs Garden}

A herbs garden is located just in front of the Infocenter. It is an open space planted with selected tropical herbs annotated for public viewing and education.

\subsection{Mangrove Walk}

Along the beach next to the Infocenter and the Botanical Garden, one can view the mangrove in its natural state by walking along the timber boardwalk. Information and signages are located at specific intervals along the walkway explaining the fauna that can be spotted regularly.

\subsection{Fossil Point}

Archeologists from Universiti Sains Malaysia discovered a promontory off Pulau Singa Besar. It was a significant finding because the fossils were believed to have been formed more than 350 million years ago. Some of the fossils were noted to have originated from the Australian continent. They have identified as many as ten fossil exhibits that were worthy for public viewing. During high tide, this promontory submerges and looks like an independent island detached from Pulau Singa Besar. An isthmus would also appear during low tide.

\subsection{Night activities}

Pulau Singa Besar offers a good spot for star gazing. The Genting Promontory has been identified as the best location for the purpose. A dormitory is provided for the enthusiasts to rest before getting up early in the morning to view the stars.

In addition, a night tour operation is planned where tour guides take visitors into the forest to see the night fauna along the Perdana Trail and other minor trails. Among the animals they can expect to see include: mousedeers, bats, big spiders, wild boars, monkeys etc. 


\subsection{Biodiversity on the island}

There are several species of plants, birds, fishes, insects and animals on the island and that makes it a good real life-size laboratory for research, education and public awareness on what a typical tropical island has to offer. A snake indigenous only to the island and not found anywhere else in peninsula Malaysia has also been identified. A Frog Pond was designed and built to accommodate at least ten different species of frogs found on the island. The frogs are located in a reasonable sized cage with lights at night to attract flying insects as fodder for the frogs. They are contained in the cage for viewing for the public so that they are easily identified.

A Worm House is also located on the island. The worms convert organic materials into manure for recycling as fodder for plants. Fallen leaves which are abundant at Pualau Singa Besar are churned into manure and the process can be observed at the Worm House. In addition, there are various locations where boatmen would feed eagles by throwing remains of chicken to the surface of the sea. The eagles would appear from all directions in the vicinity and descend rapidly to grab the food, thus creating an interesting show for tourists.

\section{The passive approach}

Wallace and Pearce [8] suggested that an ecotourism site should minimize the negative impact to the environment. Passive systems do not generate thermal pollution because they do not require external energy input and produce no byproducts or waste [10]. Interest in the passive approach is strong because it is simple in concept, requires only few moving parts and needs little or no maintenance. Pulau Singa Besar relies solely on a passive solar system for its electricity supply.

\subsection{Passive solar system in Pulau Singa Besar}

The Infocentre is powered by a set of eighty-six amorphous solar panels located along the walkway from the Jetty. This photovoltaic system is designed to supply $4 \mathrm{~kW}$ of energy although the actual amount of supply generated will depend greatly on the weather. The supply of electricity obtained via the panels is stored in batteries located at the Infocentre. This system provides solar electricity for the liquid emission diodes, emergency lighting, electric ceiling fans, computer system and electric extractor fans used in the Infocentre.

For comparison, a typical house would use $3 \mathrm{~kW}$ of energy per day. It is the first of its kind and probably the largest installation of amorphous solar panels in the region of South-East Asia. This system of using the sun's energy as a renewable energy is clean, low maintenance and operates at minimum running cost. It is also a very appropriate solution for Pulau Singa Besar as the conventional way of providing electricity generated by burning fossil fuel would be expensive because the conventional method requires getting electrical supply from mainland Langkawi via cable underneath the sea. 


\subsection{Solar electric boat}

A solar electric boat was introduced to carry a maximum of six passengers from the PSB Jetty to either the Fossil Point or to the mangrove swamp. It is powered by batteries (the power comes from the solar panels). A solar electric boat is a most appropriate vehicle to take tourists to the mangrove swamps to observe the flora and fauna because it is silent and therefore would not scare the fauna away from its habitat unlike the noisy diesel engine boats which are presently being used.

\subsection{Passive design approach for the Infocentre}

During the upgrading of the island, the existing Infocentre has been renovated to provide more exhibition space for the public. Existing walls were demolished and extended to the outer perimeter of the corridor. During the renovation, passive solar design elements were introduced to increase comfort. The passive approach prevents heat build up without having to depend heavily on mechanical aids.

During the renovation, the original stilted design was maintained as cool breeze flowing underneath the building helps to cool the floor. Door height window leafs are introduced to capture any wind velocity into the building during daytime to cool the interior. Fixed timber louvered openings were located right above the door height windows. This is to cool the roof space. Timber material is preferred in order to maintain harmony with the natural setting. Powered by solar, two turbine ventilators help release hot air from the building. However, during the dry season, these elements may not be effective enough to provide reasonable comfort. Therefore, the help of mechanical aids such as electric fans and extractors are required. In addition, as much green area is maintained around the area and that hard landscaping is reserved for pathways and for the area under the Infocentre, which is mainly used for storing the batteries for the solar panels and to avoid the area becoming muddy during extreme high tides.

\section{Issues and problems}

\subsection{Unclear vision and direction}

The management team faces several issues and challenges in turning Pulau Singa Besar into an ecotourism spot. The balance between development and preservation, though often discussed, was not easy to practice. One of the reasons for this was due to differences in views between the stakeholders. On one end, there are those who view that the island should be sufficiently developed to attract enough tourists for it to be economically sustainable. On the other end, there are those who perceive that the island should be minimally developed and that it was irrelevant whether the island could sustain itself based on the income generated from tourist arrivals. These differences in view had affected the planning and implementation of projects on the island. 


\subsection{Illegal removal of fossilised rocks}

Another problem faced by the management team was the loss of valuable fossilized rocks from the Fossil Point due to illegal collection by irresponsible parties. The area affected by this problem was mainly the southern part where large amounts of fossilised rocks are available. These rocks were mainly taken for use in the construction industry. It was a great concern because these parties were destroying invaluable national heritage.

This was an ongoing issue despite numerous warnings and attempts taken to eradicate the problem. It was almost impossible to monitor these activities because of the size of the area and the lack of manpower and financial resources to do so.

\subsection{Litter}

The abundant amount of rubbish around and on the island was also a major problem for Pulau Singa Besar. There are two different issues relating to this matter. The litter on the island were mainly due to the rubbish thrown by visitors despite the warning and penalty imposed on offenders. The lack of implementation was again partly to blame.

The huge amount of rubbish on the shores of Pulau Singa Besar was also providing a setback for the management team. Despite numerous attempts to clean the rubbish, a lot of rubbish from mainland Langkawi and from foreign vessels has been washed ashore by waves towards the beaches of the island. Floating sediments are difficult to curb as it comes from multi-direction as dictated by the wind forces that determine the direction of the waves.

In a research project funded by UNEP, high levels of suspended sediments, low dissolved oxygen and high biochemical oxygen demand have been identified as the main concerns for the coastal regions around Langkawi Island [11]. These environmentally poor conditions may be hazardous to public health and have harmed some coral ecosystems. Unless this issue is addressed seriously, the coral ecosystem of Pulau Singa Besar will suffer significantly.

\section{Conclusion}

Pulau Singa Besar has a lot to offer to the ecotourists. From nature trail to fossilized rocks, the island has abundant natural resources. However, the attempt to develop the island into a Science and Technology showcase in line with the principles of ecotourism had its fare share of success as well as failure. The use of passive solar energy to run the island was a brilliant accomplishment as it gave various ecological benefits. It was clean, easy and cheap to maintain despite costing a huge amount of money to install. In fact, in the long run, it would prove to be more economical. In addition, the solar powered boat used to bring visitors to the site contributed minimal pollution and intrusion to the wildlife.

However, different views on how to develop the island among the stakeholders resulted in various poor projects being implemented. Some projects 
on the island were mainly set up to attract tourists although not in line with the concept of ecotourism. The lack of public awareness on the importance of preserving natural heritage is a major concern in developing countries like Malaysia. More effort in educating the public should be emphasised. Focus should also be on the values of preserving nature.

\section{References}

[1] World Commission on Environment and Development, Our Common Future, Oxford: Oxford University Press, 1987.

[2] Globe 90', An Action Strategy for Sustainable Tourism Development, Ottawa: Tourism Canada, 1990.

[3] Orams, M.B., Towards a more desirable form of ecotourism, Tourism Management 16(1), pp. 3-8, 1995.

[4] Higgins, B. R., The global structure of the nature tourism industry: ecotourists, tour operators and local businesses, Journal of Travel Research 35(2), p.p 11-18, 1996.

[5] Boo, E., Ecotourism: The Potentials and Pitfalls, Washington D.C: World Wildlife Fund, 1990.

[6] Goodwin, H., In pursuit of ecotourism, Biodiversity and Conservation 5(3), pp. 129-133, 1996.

[7] Laarman, J.G \& Durst, P.B., Nature travel and tropical forests, FPEI Working Paper Series, Southeastern Centre for Forest Economic Research, Northern Carolina State University, Raleigh, 1987.

[8] Wallace, G.N. \& Pierce, S.M., An evaluation of ecotourism in Amazonas, Brazil, Annals of Tourism Research 23(4), pp. 843-873, 1996.

[9] Leiper, N., Tourist attraction systems, Annals of Tourism Research 17(3), pp. 367-384, 1990.

[10] Mazria, E., The Passive Solar Handbook, Pa: Rodale Press, 1979.

[11] Koh H.L. Din, Z. \& Lee, H.L., Modeling Water Quality in Selat Kuah, Langkawi, Malaysia. Final Report. Penang: Universiti Sains Malaysia, 1995. 